\title{
Stanley on Ideology, Or How To De-Moralise Democracy
}

\author{
Enzo Rossi \\ University of Amsterdam ${ }^{I}$
}

o.

Notice the hyphen in my title. It indicates that Jason Stanley's How Propaganda Works ${ }^{2}$ has the potential to reinvigorate democracy by providing a non-moralistic case for it, not that it makes us lose confidence in democracy. And that is one reason why this is an important book: in my reading, it is a contribution to the realist revival in political philosophy, ${ }^{3}$ insofar as it defends non-trivial normative conclusions without recourse to moral values external to politics. There are other reasons too. The book helps reviving ideology critique, thus broadening the scope of scope of AngloAmerican political philosophy. And it does so by combining tools from analytic epistemology and philosophy of language with current empirical results in psychology and other social sciences-an achievement that shows the untapped potential of presumptively apolitical fields of philosophy and reclaims political philosophy's traditional haunt between facts and values from the rarefied purely normative terrain where its Anglo-American mainstream consigned it over the past few decades - or from moralism, as political realists would say.

The book's core argument can be crudely and provisionally summarised as follows. Democratic societies require substantial material equality because inequality causes ideologically flawed belief, which, in turn, make demagogic propaganda more effective. And that is problematic for the quality of democracy.

In what follows I will unpack that argument, in order to make two points: (a) the non-moral argument for equality is promising, but weakened by its reliance on a heavily moralised conception of democracy; (b) that problem may be remedied by whole-heartedly embracing a more realistic conception of democracy. That conception is at least compatible with Stanley's argument, if not implicit in parts of it.

\section{I.}

The extremely condensed summary of Stanley's argument in the previous section indicates that it has a normative

\footnotetext{
1 Department of Political Science, Roeterseiland Campus, Po.box 15578, 1001NB Amsterdam, The Netherlands. E.Rossi@UvA.nl.

2 (Princeton, NJ: Princeton University Press, 2015). Hereinafter all unspecified parenthetical page references are to this book.

${ }^{3}$ For an overview of this current see Rossi and Sleat (2014).
} 
conclusion-a defence of egalitarian democracy—supported by conceptual as well as empirical considerations. And one may reasonably infer that moral considerations play a role there too (as I argue in the next section), though I will try to show that they need not play a role (as I argue in the final section). For now I will just set the stage by outlining those considerations and the way in which they fit together. Here is a slightly more formal presentation of the core argument. ${ }^{4}$

PI: Material inequality causes ideologically flawed belief.

P2: Ideologically flawed belief makes demagoguery - a species of propagandaeffective.

P3: Demagoguery is problematic for the quality of democracy.

C: Material inequality is problematic for the quality of democracy.

I take it that the argument is straightforwardly valid, so we should focus on the content of the premises. It should be fairly clear that the first two premises will require support from epistemology, philosophy of language, and social-science. The third one does too, as well as from political philosophy, and that is why the word 'quality' there may raise some eyebrows, especially as it is deployed in close proximity to the word 'democracy'. We noted earlier that one of the distinctive features of Stanley's argument for equality is that it is nonmoral, yet mention of the quality of democracy may point to moral commitments. We will turn to that issue later. For now let us focus on the first two premises, just to give a sense of the argument's scope. I cannot do justice to Stanley's resourceful interdisciplinary argumentation here, so I will limit myself to a bare, indeed partial outline of his case for each of the first two premises.

The first premise combines empirical material from social psychology and other social sciences with a novel account of flawed ideology that draws on Stanley and others' recent work in epistemology and cognate fields, especially the philosophy of mind. The starting point is a familiar one. The social structures and practices in which we live are tied up with our social identities, and (some of) our beliefs result from the interaction of social structures and social identities. Those are ideological beliefs, in a neutral sense of the term. Stanley then moves on to argue that flawed social structures-specifically, anti-egalitarian social structures-generate flaws in some of our ideological beliefs. Flawed ideological beliefs, according to Stanley, are beliefs that are resistant to rational revision: "difficult to abandon false belief[s] the presence of which hinders the acquisition of knowledge." (199) The key move here is to flesh out resistance to rational revision as "a purely epistemic notion of flaw" (I80), so that the link between

\footnotetext{
${ }^{4}$ For clarity and brevity I present the argument in a way that does not follow the order in which the various points are introduced in the book. But my account of the core claims aims at fidelity to Stanley's text.
} 
inequality and flawed ideology does not depend on a prior negative moral judgment on inequality. For our present purposes we can grant this point, which in any case is a persuasive one.

The second premise, which we can similarly grant, rests on an analysis of the concept of propaganda, and particularly of what Stanley calls 'undermining propaganda': "Undermining propaganda by its nature undermines a political ideal. It undermines a political ideal by using it to communicate a message that is inconsistent with it." (57) That is to say, undermining propaganda uses an ideal against itself. Demagoguery - which we will analyse in the discussion of the third premise - is a species of undermining propaganda. For now it will suffice to highlight Stanley's claim that undermining propaganda "is able to achieve the task [of undermining ideals it ostensibly supports] by exploiting already existing flawed ideological belief, and even contributing to the formation of such belief. It is flawed ideological belief that masks the contradictions of undermining propaganda ... by erecting difficult epistemic obstacles to recognizing tendencies of goals to misalign with certain ideals" (Ibid., emphasis in original). That claim also relies on results from traditionally non-political areas of philosophy and from social science. We cannot probe those results or their combination here, but it is important to notice that no moral commitments are required to establish this premise either.

The third premise is in need of most clarification, given its normative claim, which is then carried through to the conclusion. I will parse that normative claim over the next two sections.

\section{2.}

In what sense, exactly, is demagoguery problematic for the quality of democracy? If that sounds like a loaded question, that is because it is. The suggestion here is that Stanley may have smuggled some moral commitment into an ostensibly non-moral argument. I take for granted, for now, that advancing a non-moral argument for egalitarianism is a desideratum here, but I will say something more about why that is so in the next section.

Stanley argues that within democracies, ${ }^{5}$ a specific kind of undermining propaganda is most deleterious: "The kind of propaganda that is most threatening to liberal democracy is a species of undermining propaganda we may call demagoguery. Demagoguery is propaganda in the service of unworthy political ideals. What counts as demagoguery therefore depends on moral and political facts." (68) Stanley then acknowledges that the worthiness of political ideals is controversial, but given the book presupposes rather than defends a commitment to democracy, "It is therefore safe to assume ... that the liberal democratic ideals of liberty,

${ }^{5}$ Like Stanley, I use 'democracy' and 'liberal democracy' interchangeably, unless otherwise specified. 
humanity, equality, and objective reason are worthy ideals. In the case of a liberal democratic state, demagogic speech includes speech that uses liberal democratic ideals in the service of undermining these ideals. (Ibid.)

Now it should be fairly clear why that account of democratic ideals may imperil the project of offering a nonmoral argument for democracy. It would not be much of a problem if the book's argument supported a set of moral ideals with non-moral considerations. But the worry here is that there may be a closer connection between the non-moral, epistemic argument and the moralised conception of egalitarian democracy it supports. It may be that the nonmoral argument for equality only works within the context of a moralised conception of democracy, in which case, why not offer a standard moral argument for material equality directly?

Some of Stanley's claims may lend credence to that worry, especially his adoption of a broadly Rawlsian, public reasoncentred understanding of democracy's value: "In a democracy ... among the central ideals are normative ideals governing public political speech. ... one is central: the ideal that John Rawls has called 'reasonableness'." (8I) Rawlsian reasonableness is a notoriously controversial notion, especially on the Eastern shores of the Atlantic. It combines a set of epistemic and moral criteria, ranging from a requirement to uphold the uncontroversial findings of science to a commitment to treating others with the respect due to free and equal citizens. It is the latter aspect of Rawlsian reasonableness that is worrisome here. In Stanley's interpretation, reasonableness is about taking all perspectives into account by adopting a second-personal attitude:

Second-personal attitudes thus centrally involve the notions of dignity and respect. If the adoption of second-personal attitudes is a precondition governing public deliberation in public political forums, then speech that is an affront to the dignity of other members of society runs counter to these ideals, and hence is the kind of speech that one expects to find masked paradigmatically by propaganda. (I09, emphasis in original)

But do we really need such a moralised conception of democracy for the non-moral argument for material equality to kick in? I turn to that question in the next section.

\section{3.}

I want to show that there are at least three possible readings of Stanley's argument for equality, and that only one of them falls victim to the worry raised in the previous sections. I will label the arguments moral, performative, and epistemic. I will then argue that the first is inconsistent with the book's aim, the second is consistent but somewhat problematic in other respects, and the third is both consistent and most promising.

The moral argument says that demagoguery is bad for democracy because, crudely, it makes us disrespect others by not relating to them in a reasonable way (in the Rawlsian, moralised sense of 'reasonable'). As we have seen, the problem 
here is that this kind of disrespect makes the badness of inequality depend on the moral badness of disrespect. In which case, why bother with a non-moral argument for equality in the first place?

I labeled-somewhat inaccurately-the performative argument after the notion of a performative contradiction. A performative contradiction occurs when the propositional content of a statement contradicts the presuppositions of asserting it. This is roughly analogous to something Stanley says about how undermining propaganda works: "Undermining propaganda involves a kind of contradiction between ideal and goal. It's an argument that appeals to an ideal to draw support, in the service of a goal that tends to erode the realisation of that ideal." (53, emphasis added) This is not a moral argument, so it is safe from the worry outlined earlier. But I want to suggest that it may suffer from excessive intellectualism, at least insofar as the book's argument is intended as a live contribution to pressing political problems. By that I mean that politics is largely about muddling through, not about avoiding contradictions. Philosophers involved in public policy discussions, for instance, often frown at policymakers relaxed attitude towards contradictory policy measures: "Yes, professor, policy A pulls against the aims of policy B, but they are five years apart anyway!". Letting demagoguery flourish may undermine democracy in some way, but also be important to it in some other way - some way I am not going to explore here, as I am merely interested in highlighting the possibility. In fact, to be fair, Stanley does not argue that demagoguery destroys democracy, but only that it is a risk factor for it. But that does not in and of itself provide a conclusive argument for equality, which one may take to be the book's aim. In politics we trade off risk factors against prospected benefits and other risks, and hope for the best. So this performative argument is not a problem for the structure of Stanley's argument (unlike the moral one), but it does establish the book's desired conclusion. Admittedly it is hard to see exactly what kind of argument would establish such an ambitious conclusion. The more important point here is that the performative argument is unlikely to have much political salience. But it is a strong argument for the philosophy seminar room.

The epistemic argument hones in on another reading of the claim that demagoguery imperils the quality of democracy, namely one focused on the epistemic properties of democratic deliberation: "Propaganda that is presented as embodying an ideal governing political speech, but in fact runs counter to it, is antidemocratic. It is antidemocratic because it wears down the possibility of democratic deliberation. Such propaganda is demagoguery." (82-3) And further: "Flawed ideological beliefs corrode rational debate." (86) So the idea here is to understand the quality of democracy as concerned with a non-moralised account of collective decision-making quality. This is a type of part-empirical and part-conceptual argument recently advanced most prominently by Hélène Landemore (20I2), 
among others. ${ }^{6}$ Landemore makes a powerful case for the epistemic advantages of collective decision-making (under certain conditions). In fact Stanley refers to Landemore's work (90), though in that passage he assimilates her argument to the far more moralised epistemic case for democracy offered by David Estlund (2008), who stresses the moral ills of rule by experts. Focusing more narrowly on the purely epistemic case for a democratic deliberation untainted by demagoguery would assuage the moralism worry we discussed in section 2. And it would resonate with Stanley's already fairly streamlined version of reasonableness as an epistemic requirement (Io8ff, I22), as well as with his anti-technocratic and anti-authoritarian critique of expert rule (40).

On this epistemic reading of the book's core argument the point of democracy would be to maximally equalise the empowerment of each citizen. Crudely, democracy's distinctiveness is its ability to diffuse power, rather than its instantiation of some moral ideal. Democracy is a tool for power-sharing, for achieving stability - all distinctly political rather than moral values. ${ }^{7}$

Does jettisoning the moral argument have a cost, though? Setting aside the worry flagged above, that depends on one's overall methodological commitments in political philosophy. One may think that showing the congruence between one's first order political position and some appealing moral, prepolitical values is a plus. Or one may think that reliance on pre-political moral commitments does not help in political philosophy - it may even hinder one's case, as moral beliefs or intuitions are some of the most ideological distortion-prone human practices, ironically enough in this context. ${ }^{8}$ At any rate, by adopting this more realistic epistemic conception of democracy none of the politically salient egalitarianism is lost, but only the bourgeois liberal moralism of equal respect and Rawlsian reasonableness. Good riddance.

\footnotetext{
${ }^{6}$ For a critique see Brennan (2016).

${ }^{7}$ I defend this distinction in Jubb and Rossi (2015).

${ }^{8}$ I defend this claim in Rossi (2016) and Prinz and Rossi (2017).
} 


\section{References}

Brennan, J., 20I6. Against Democracy. Princeton, NJ: Princeton University Press.

Estlund, D., 2008. Democratic Authority: A Philosophical Framework. Princeton, NJ: Princeton University Press.

Jubb, R. \& Rossi, E., 20I5. Political Norms and Moral Values. Journal of Philosophical Research, 40: 455-458.

Landemore, H., 2012. Democratic Reason: Politics, Collective Intelligence, and the Rule of the Many. Princeton, NJ: Princeton University Press.

Prinz, J. \& Rossi, E., 20I7. Political Realism as Ideology Critique. Critical Review of Social and International Political Philosophy (forthcoming).

Rossi, E. \& Sleat, M., 20I4. Realism in Normative Political Theory. Philosophy Compass, 9/I0: 689-70I.

Rossi, E., 20I6. Facts, Principles, and (Real) Politics. Ethical Theory and Moral Practice, I9: 505-520. 